\title{
Synthesis and Evaluation of the Fungal Activity of New Pyrazole-Carboxamides against Colletotrichum gloeosporioides
}

\author{
Edwin González-López, ${ }^{a}$ Jhair León-Jaramillo, ${ }^{a}$ Jorge Trilleras, ${ }^{\oplus *, a}$ \\ Carlos D. Grande-Tovar, ${ }^{b}$ Yeimmy Peralta-Ruiz, ${ }^{c, d}$ and Jairo Quiroga ${ }^{e}$ \\ ${ }^{a}$ Grupo de Investigación en Compuestos Heterocíclicos, Programa de Química, \\ Facultad de Ciencias Básicas, Universidad del Atlántico, Carrera 30 Número 8-49, \\ 81007 Puerto Colombia, Atlántico, Colombia \\ ${ }^{b}$ Grupo de Investigación en Fotoquímica y Fotobiología, Programa de Química, \\ Facultad de Ciencias Básicas, Universidad del Atlántico, Carrera 30 Número 8-49, \\ 81007 Puerto Colombia, Atlántico, Colombia \\ 'Facultad de Ingeniería, Programa de Ingeniería Agroindustrial, Universidad del Atlántico, \\ Carrera 30 Número 8-49, 81007 Puerto Colombia, Atlántico, Colombia \\ ${ }^{d}$ Faculty of Bioscience and Technology for Food, Agriculture and Environment, \\ University of Teramo, Via R. Balzarini 1, 64100 Teramo, Italy \\ ${ }^{e}$ Grupo de Investigación de Compuestos Heterocíclicos, Departamento de Química, \\ Universidad del Valle, A. A. 25360 Cali, Valle del Cauca, Colombia

\begin{abstract}
The pyrazole core has been recognized by their biological properties and included in the synthesis of modern agrochemicals. Part of these studies consists of making structural modifications to pesticides for commercial purposes to increase efficacy. In this article, we present the synthesis of four new pyrazol-4-carboxamide 8a-8d derivatives (PCD), through a four-step synthetic protocol, starting with edaravone $\mathbf{1}$ and primary amines like benzo-fused, aliphatic, and hydrazines, through a process of low environmental impact. Synthesized derivatives were evaluated against one fungal strain of Colletotrichum gloeosporioides BA3, fungus that causes several losses to farmers around the world, through in vitro sensitivity tests. The compound $\mathbf{8 c}$ showed better inhibiting behavior against Colletotrichum gloeosporioides BA3, inducing a lag phase of almost 2.77 days. These results were obtained via Gompertz modeling, for the first time reported for biological evaluation of pyrazole-carboxamide derivatives against Colletotrichum gloeosporioides.
\end{abstract}

Keywords: agrochemicals, antifungal agent, Colletotrichum gloeosporioides, nitrogen heterocycles, pyrazole carboxamide

\section{Introduction}

During 40 years, Colombia has been developing and implementing different strategies for the consolidation of agribusiness, in terms of improved productivity and production efficiency. Strategies directed from the analysis of agribusiness, in parallel to the policies and agendas of competitiveness, research, and innovation of the state for the development of productive chains. At the phytosanitary level, an important aspect for the incorporation of agricultural products to the foreign market, advances in

*e-mail: jorgetrilleras@mail.uniatlantico.edu.co technology and procedures for pest management, and the production of biopesticides has been developed for crop protection. As a result, healthy growth of crops using stable agrochemicals based on biopesticides has been implemented..$^{1,2}$ However, the increased demand for healthy food, reduced availability of land (rural areas affected by illegal mining and crops), genetically modified crops, new pest species, and new agricultural practices, are factors trends towards the use of modified synthetic pesticides without adverse environmental effects.

In this sense, the chemical protection of crops to reduce the incidence and severity of pests and diseases remains in force. In order to maintain the increase in crop production 
and meet growing population demands regarding quality and quantity of food, fungicides are still widely used to protect against agricultural diseases that threaten its safety and efficient production. ${ }^{3,4}$ However, considering the dependence of traditional products, there is a trend towards the use of compounds to control pests and diseases, with low environmental impact. While this trend remains, there is a high demand for products with a significant reduction in terms of toxicity and residual effect on the environment. Accordingly, the modern agrochemical industry has developed pesticides to control diseases and pests in crops worldwide, including rice, onion, apple, cucumber, among others. Currently, herbicides and pesticides containing the pyrazole nucleus are commercialized (Figure 1), with the ability to protect certain plants from a wide range of diseases and pests. ${ }^{5-8}$

Colletotrichum gloeosporioides is present throughout the Caribbean and is the main cause of different diseases such as anthracnose in more than 450 host plants such as avocado, corn, and banana, ${ }^{9-13}$ and considered one of the most serious problems for growers in Colombia and around the world. ${ }^{14}$ C. gloeosporioides is also very severe as a postharvest disease, affecting several fruit crops ${ }^{15}$ Papaya and mango crops in Colombia have around $25-40 \%$ of post-harvest losses due to this phytosanitary problem. ${ }^{16}$

These crops are of great importance worldwide and are used as the main ingredients in basic food for humans and animals. The reports ${ }^{17-19}$ of the biological properties of some pyrazole derivatives in the protection of crops highlight that their activity is associated to the pyrazole nucleus with groups or structural fragments such as isothiocyanate, $\beta$-methoxyacrylates, aliphatic chains, carboxamides, alkoxides, and halogens. In general, electron-rich groups in aromatic rings can increase their effectiveness. However, increasing microbial resistance to known antibiotics creates an urgent need to develop new agrochemicals..$^{20-22}$

Continuing with the research in synthesis of nitrogen heterocyclic systems, specifically pyrazole derivatives, starting from carbonyl precursors, this work extends the synthetic alternatives to obtain new pyrazole-based compounds and explores potential applications for chemical crop protection, demonstrating a broad application in the agrochemical industry. ${ }^{23,24}$

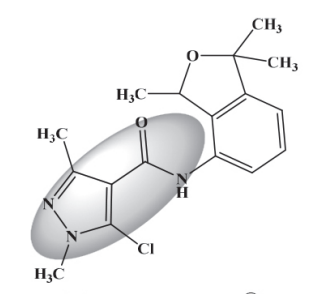

Furametpyr ${ }^{\mathbb{B}}$

Alta Scientific Co., Ltd.

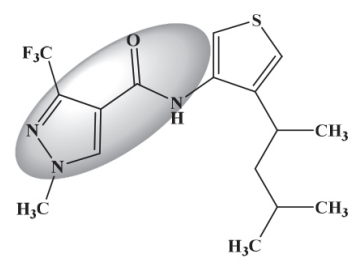

Penthiopyrad Fontelis ${ }^{\circledR}$, DuPont

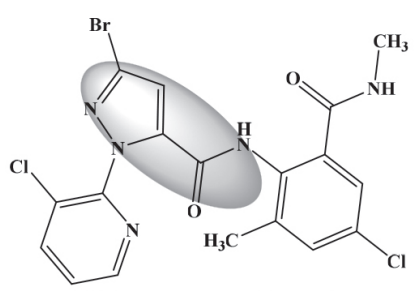

Chlorantraniliprole Coragen ${ }^{\circledR}$ SC, DuPont

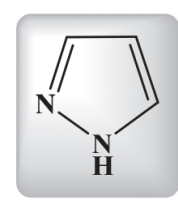

Pyrazole

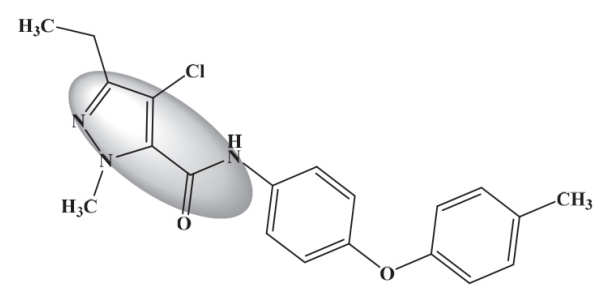

Tolfenpyrad

OMI 8815 EC $^{\circledR}$, Nihon Nohyaku Co. Ltd.

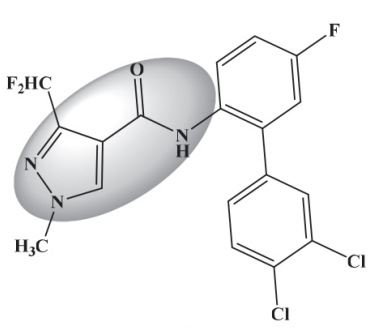

Bixafen $^{\circledR}$, Bayer

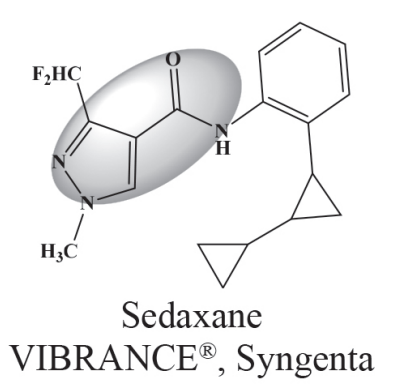

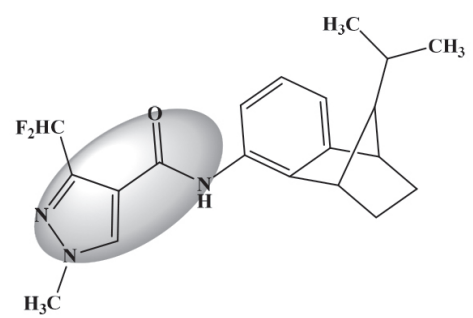

Isopyrazam

Reflec ${ }^{\circledR}$ XTRA, Syngenta

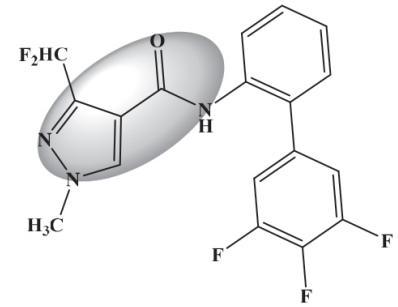

Fluxapyroxad $^{\circledR}$, BAS $700 \mathrm{~F}$

Figure 1. Pyrazole core and active ingredient structures in commercial agrochemical applications. 


\section{Results and Discussion}

\section{Synthesis}

According to the structural relationship of commercial agrochemical agents (Figure 1) and reports ${ }^{17,23,25}$ of advances in research on new agents for chemical crop protection, pyrazole-carboxamide derivatives (PCD) are an important category of these compounds. Numerous reports ${ }^{17,18,23-25}$ highlight the agrochemical potential of the substituted pyrazole-carboxamide derivatives used to control destructive plant's pathogens. This structural fragment consists of a substituted pyrazole carboxyl "core", and conserved amide function, structural characteristics to which biological activity has been associated (Figure 2). ${ }^{20,25}$ Considering the structural importance of the pyrazole nucleus, synthetic strategies are established for obtaining PCD, from simple or commercially available materials.

These synthetic strategies for obtaining PCD involves high oxidation process to incorporate carboxyl group into the core's pyrazole through a Vilsmeier-Haack reaction. The oxidation reaction with the Vilsmeier-Haack reaction is the most complicated stage of the synthetic methodology. Then, the amide bond is formed by a substitution reaction (Scheme 1).

The oxidation reactions are carried out with a mixture of $\mathrm{KMnO}_{4} / \mathrm{H}_{2} \mathrm{O},{ }^{26-29} \mathrm{KMnO}_{4} / \mathrm{H}_{2} \mathrm{O}$-pyridine, ${ }^{30}$ or acid $\mathrm{K}_{2} \mathrm{Cr}_{2} \mathrm{O}_{7} \cdot{ }^{31}$ Reactions with $\mathrm{SOCl}_{2}$ generate the respective acid chloride. ${ }^{32,33}$ Methodologies can also been explored for obtaining esters ${ }^{30}$ and free amides. For the preparation of the pyrazole-carboxamides derivatives, we have carried out a Vilsmeier-Haack reaction on 5-methyl-2-phenyl2,4-dihydro-3H-pyrazol-3-one (1, edaravone), a free radical scavenger originally developed for treatment of stroke, ${ }^{34,35}$

\section{Pyrazole Scaffold}

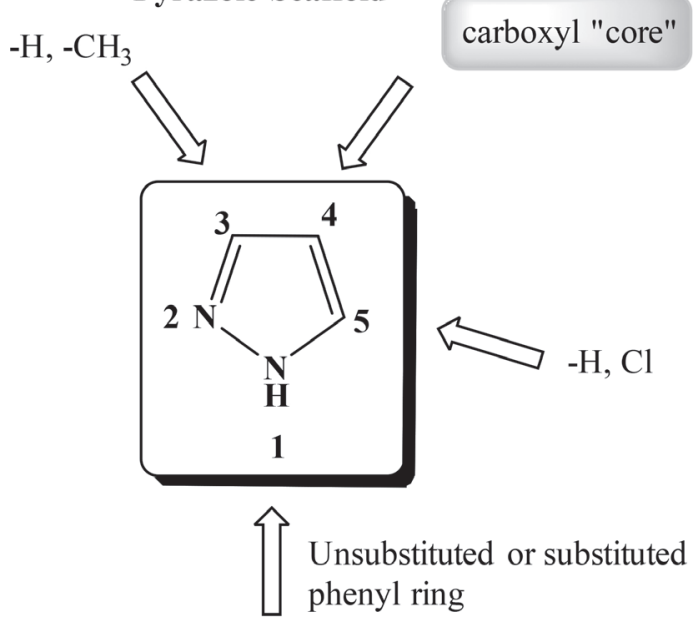

Figure 2. Structural requirements for pyrazole-carboxamides derivatives synthesis.

to generate 5-chloro-3-methyl-1-phenyl-1H-pyrazole4-carbaldehyde (2) with $70 \%$ yield (Scheme 2 ).

Initially, for the oxidation of pyrazole-4-carbaldehyde (2), potassium permanganate $\left(\mathrm{KMnO}_{4}\right)$ in an equivalent ratio of 1:3 in aqueous medium reflux heating was used. However, the yield was not satisfactory due to the low solubility of the precursor in water. Therefore, conditions were changed to a $3: 2$ ratio of water:acetone mixture with a temperature reaction of $80{ }^{\circ} \mathrm{C}$, during $4 \mathrm{~h}$. The end of the reaction was verified by thin layer chromatography (TLC). After that, the $\mathrm{pH}$ was adjusted to 2 with $\mathrm{HCl}$, isolating a white solid by vacuum filtration (yield $95 \%$ ), corresponding to 5-chloro-3-methyl-1-phenyl-1H-pyrazole-4-carboxylic acid (3). Compound $\mathbf{3}$ was used directly in the next step for the acid halide formation. Simple variations were made on synthetic steps of known methodologies and reactions, ${ }^{26,36,37}$ in order to improve our conditions (higher yields in lower times). In previous works, this synthetic route was used
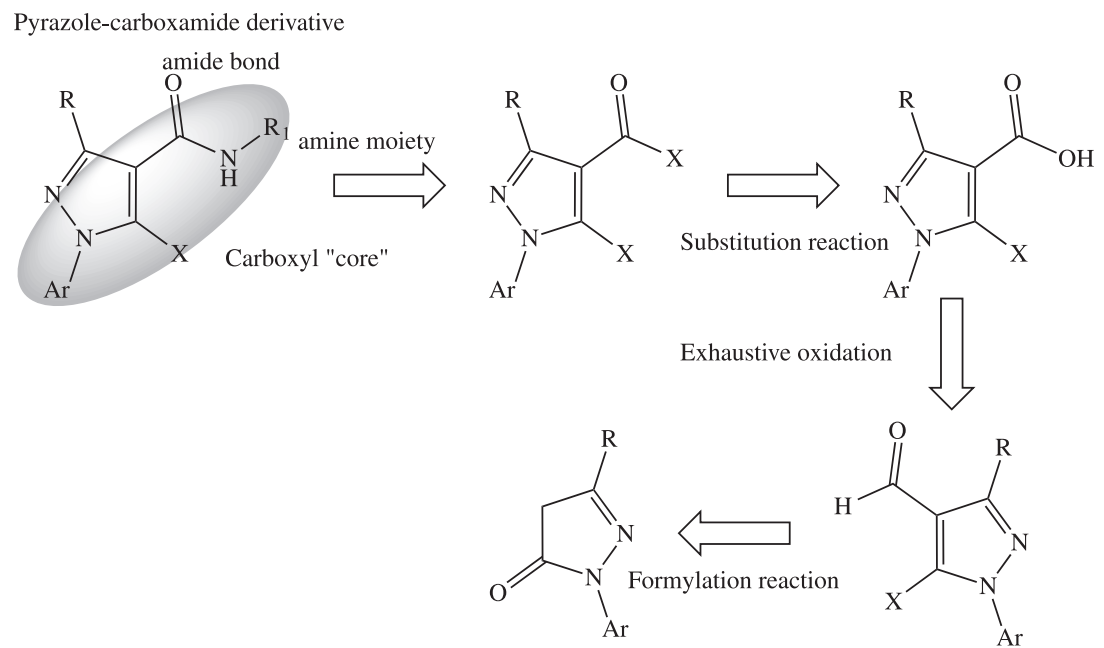<smiles>[R]c1nn([Al])c([X])c1C=O</smiles>

Scheme 1. Retrosynthetic strategy for the preparation of pyrazole-carboxamides derivatives (PCD). 

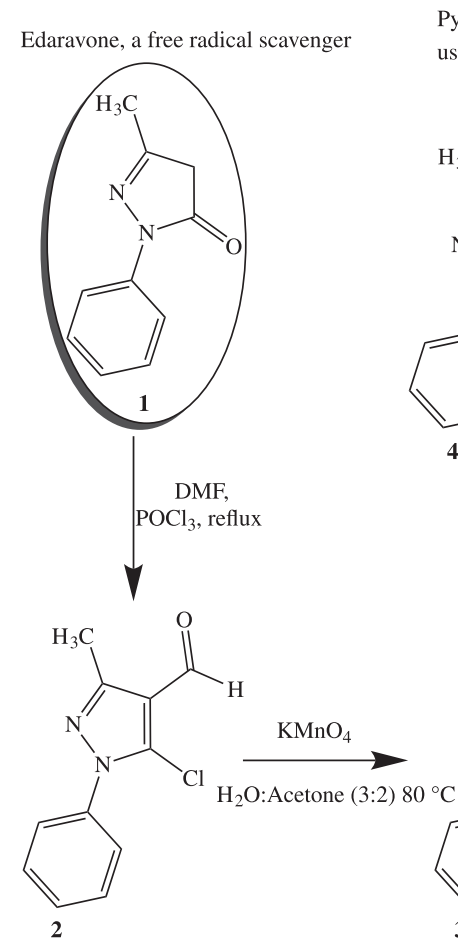

2
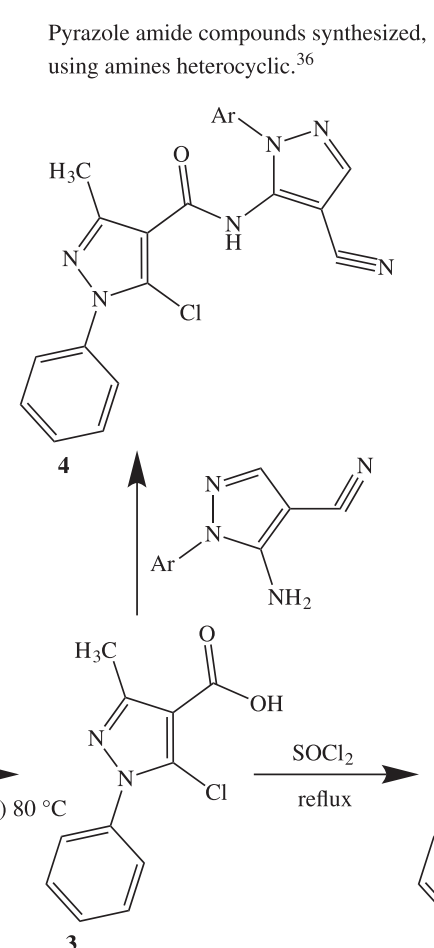

Pyrazole amide compounds synthesized, using anilines. ${ }^{26}$<smiles>CCNC(=O)c1c(C)nn(-c2ccccc2)c1Cl</smiles>

6
Amines used in this work

$\mathrm{R}_{1} \mathrm{NH}_{2}$<smiles>Nc1ccc2ccccc2c1</smiles><smiles>COc1ccc(CN)cc1</smiles>

$\mathrm{H}_{2} \mathrm{~N}_{\mathrm{NH}}$<smiles>Cc1ccc(S(N)(=O)=O)cc1</smiles>

$\mathrm{RNH}_{2}, \mathrm{THF}, \mathrm{Et}_{3} \mathrm{~N}$, r.t., $8 \mathrm{~h}$<smiles>Cc1nn(-c2ccccc2)c(Cl)c1C(=O)Cl</smiles>
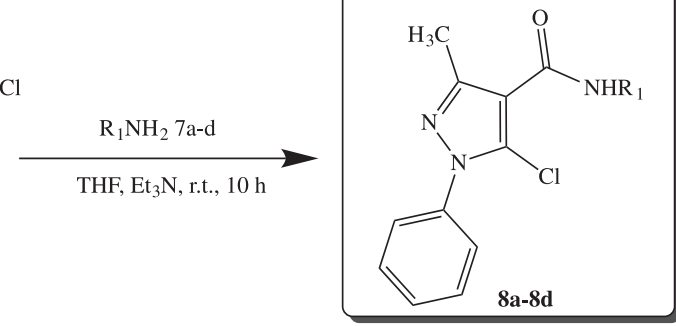

Scheme 2. Synthesis of the pyrazole-carboxamide compounds $\mathbf{8 a - 8 d}$.

to obtain pyrazole-carboxamide derivatives $\mathbf{4}$ and $\mathbf{6}$, using heterocyclic amines ${ }^{36}$ and anilines, ${ }^{26}$ as amine moiety. Compounds $\mathbf{4}$ are obtained by an aminolysis reaction on the carboxylic acid, while derivatives $\mathbf{6}$ are obtained via the reaction sequence to the respective acid halide $\mathbf{5}$.

Once 5-chloro-3-methyl-1-phenyl-1H-pyrazole4-carbonyl chloride (5) was obtained, the excess of $\mathrm{SOCl}_{2}$ was removed following the reported procedure. ${ }^{26}$ The resulting crude was used without previous purification, and then, tetrahydrofuran (THF), $\mathrm{Et}_{3} \mathrm{~N}$ as an organic base, and the respective amine $\mathbf{7 a - 7 d}$ were mixed. Finally, the reaction mixture was stirred at room temperature for $10 \mathrm{~h}$ to provide the respective pyrazole-carboxamide derivatives $\mathbf{8 a - 8 d}$. The reaction under stirring at room temperature gave favorable results in the presence of triethylamine. The organic base was used as an $\mathrm{HCl}$ trap, a hydrolysis barrier of the final product, and also to avoid protonation of the amine, which acts as a nucleophile and does not limit the formation of the product until it can fully consume the amount of amine supplied (Table 1).

According to the results, the substituents did not influence the yield and the reaction time. The slight increasing in yield values in compounds $\mathbf{8 b}-\mathbf{8 d}$ with aliphatic amines compared with compound 8a with naphthylamine, can be explained by the restriction of the free electron pair as a consequence of the inductive effect generated by the naphthyl ring. The

Table 1. Pyrazole-carboxamide derivatives $\mathbf{8 a - 8 d}$ obtained via four-step synthesis

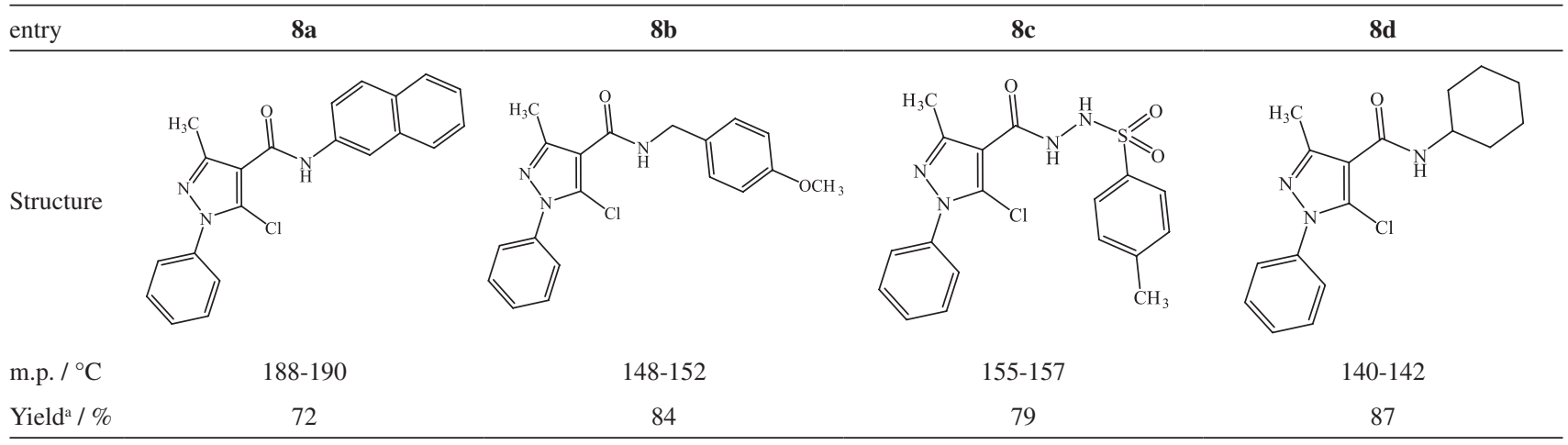

aield calculated on the amount of 5-chloro-3-methyl-1-phenyl-1 $H$-pyrazole-4-carboxylic acid (3) used. 
compounds $\mathbf{2}, \mathbf{3}$ and $\mathbf{8 a - 8 d}$ were identified and characterized by ${ }^{1} \mathrm{H}$ nuclear magnetic resonance (NMR), ${ }^{13} \mathrm{C}$ NMR, and mass spectrometry (MS). The spectral characteristics of pyrazole-carboxamide derivatives (8) highlight a chemical shift, low field signal, which corresponds to the proton of the $-\mathrm{NH}$ group of the amide bond. With the same spectral pattern, in the ${ }^{13} \mathrm{C}$ NMR experiment, the low-field signal corresponding to the carboxyl "core" is evidenced. Exploring the scope of the reaction, tests were carried out with polynuclear secondary amines (diphenylamine, $9 \mathrm{H}$-carbazole and $\mathrm{N}$-phenylnaphthalen-2-amine), without satisfactory results.

\section{Antifungal activity}

The fungal activity presented as percentage of mycelial inhibition growth (MIG) of PCD 8a-8d against the Colletotrichum gloeosporioides BA3 strain is reported in Figure 3. Overall, a decrease in fungal growth (mycelia diameter) with the increase of PCD concentration was observed. The derivative $\mathbf{8 c}$ was the compound with the highest mycelial inhibition, with 29.3, 56.1, and $61 \%$ of inhibition for derivative concentrations of 1,5 , $10 \mathrm{mM}$, respectively. The effect of pyrazole-carboxamide compounds has been reported ${ }^{38}$ in other fungal species such Physalospora piricola, Cercospora arachidicola, Phytophthora capsici and Sclerotinia sclerotiorum with an inhibition very close to commercial fungicides like fluxapyroxad.

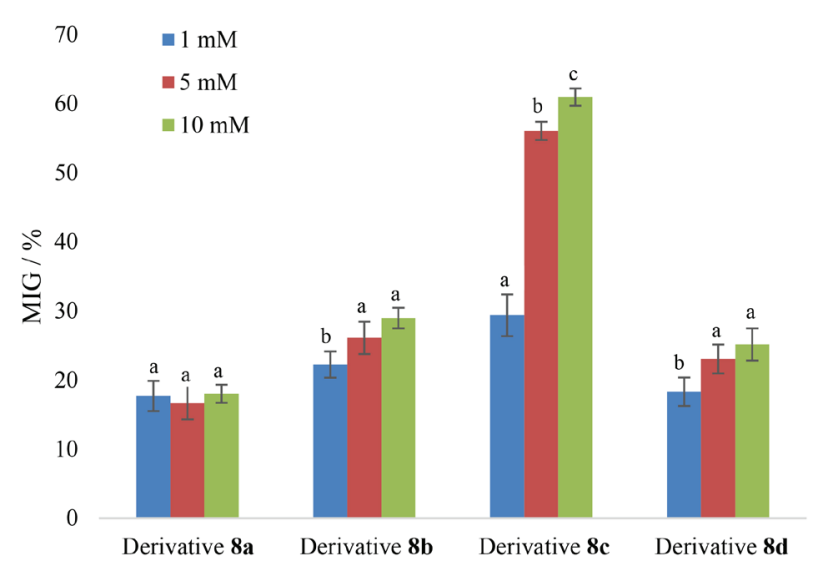

Figure 3. Colletotrichum gloeosporioides mycelial inhibition growth. Mean and standard deviation of three repetitions. Mean values and intervals of Duncan's 95\% according to the analysis of variance (ANOVA) test. Different letters $(\mathrm{a}, \mathrm{b}, \mathrm{c})$ mean significant differences between the derivatives $(p<0.05)$.

In order to evaluate the influence of the different derivatives on the $C$. gloeosporioides growth dynamics, diametral growth data were modeled using the Gompertz equation and data are reported in Table 2 . The derivatives had a significant effect on the lag phase extension and maximum growth rate. In particular, the derivative $\mathbf{8 c}$ delayed the growth for at least 2.77 days, after what it reached a diameter of growth lower than the control. This response can be considered a measure of the time that takes the cells to repair damages that occurred by stress occasioned by the derivative. ${ }^{39}$

Probably, the presence of a sulfonamide nucleus

Table 2. Influence of pyrazole-carboxamide derivatives in parameters growth of Colletotrichum gloeosporoides BA3 in PDA, calculated with the modified Gompertz equation

\begin{tabular}{|c|c|c|c|c|}
\hline \multirow{2}{*}{ Treatment } & \multirow{2}{*}{$\mathrm{PCD} / \mathrm{mM}$} & \multicolumn{3}{|c|}{ Gompertz parameter } \\
\hline & & $\mathrm{A}_{\max } / \mathrm{cm}$ & $\mu_{\max } /$ day $^{-1}$ & $\lambda /$ days \\
\hline \multirow[t]{2}{*}{ Control } & - & $3.10 \pm 0.02$ & $0.89 \pm 0.01$ & $0.43 \pm 0.01$ \\
\hline & 1 & $2.93 \pm 0.00$ & $0.86 \pm 0.01$ & $0.79 \pm 0.04$ \\
\hline \multirow[t]{3}{*}{$8 \mathbf{a}$} & 5 & $2.93 \pm 0.01$ & $0.96 \pm 0.01$ & $1.25 \pm 0.01$ \\
\hline & 10 & $2.88 \pm 0.04$ & $1.12 \pm 0.05$ & $1.48 \pm 0.05$ \\
\hline & 1 & $2.89 \pm 0.01$ & $0.76 \pm 0.03$ & $0.94 \pm 0.11$ \\
\hline \multirow[t]{3}{*}{$8 b$} & 5 & $2.80 \pm 0.01$ & $0.95 \pm 0.02$ & $1.33 \pm 0.04$ \\
\hline & 10 & $2.75 \pm 0.02$ & $1.00 \pm 0.06$ & $1.40 \pm 0.08$ \\
\hline & 1 & $2.73 \pm 0.01$ & $1.24 \pm 0.03$ & $1.98 \pm 0.01$ \\
\hline \multirow[t]{3}{*}{$8 c$} & 5 & $2.38 \pm 0.02$ & $0.90 \pm 0.03$ & $2.49 \pm 0.01$ \\
\hline & 10 & $2.28 \pm 0.07$ & $0.90 \pm 0.22$ & $2.77 \pm 0.34$ \\
\hline & 1 & $2.78 \pm 0.01$ & $1.44 \pm 0.02$ & $1.94 \pm 0.02$ \\
\hline \multirow[t]{2}{*}{$8 d$} & 5 & $2.80 \pm 0.00$ & $1.11 \pm 0.01$ & $0.76 \pm 0.02$ \\
\hline & 10 & $2.95 \pm 0.02$ & $0.76 \pm 0.22$ & $1.47 \pm 0.08$ \\
\hline
\end{tabular}

Mean and standard deviation of three repetitions. PCD: pyrazole-carboxamide derivatives; $\mathrm{A}_{\max }$ : maximum colony diameter during stationary phase; $\mu_{\max }:$ maximum growth rate; $\lambda$ : lag phase. 
in the derivative $\mathbf{8 c}$ can explain the highest antifungal activity compared to derivatives $\mathbf{8 a}, \mathbf{8 b}$, and $\mathbf{8 d}$, where this nucleus is not present. Some authors ${ }^{40-42}$ highlight that the presence of sulfonamide nucleus plays an important role in agrochemical for its excellent antifungal activity, acting on the mycelium cell membrane and reducing the content of deoxyribonucleic acid (DNA) and polysaccharide in mycelium presenting in vitro activity against Botrytis cinerea, Aspergillus flavus, Aspergillus niger, Fulvia fyulvum, Trichoderma viride. The fact of evaluating the growth dynamics of Colletotrichum gloeosporioides under the effect of derivatives is important. In fruits such as papaya, mango, and banana, the fungus remains latent until it begins its development after harvest, reducing the useful life of the fruits. ${ }^{15}$ The derivative $8 \mathbf{c}$ evaluated induces a lag phase of almost 2.77 days of the fungus with respect to the control, which makes it a promising alternative as a post-harvest strategy and the subsequent extension of the shelf life in subtropical and tropical fruits. ${ }^{43}$

\section{Conclusions}

These results exhibit a conceptually sustainable methodology for the four new pyrazole-carboxamide derivatives synthesized from edaravone, a recognized free radical scavenger. The preparation was carried out through an efficient synthesis of four steps, by incorporation of carboxylic functional group and primary amines like benzofused (naphthalen-2-amine), aliphatic and alicyclic amines ((4-methoxyphenyl)methanamine and cyclohexanamine), and hydrazines (4-methylbenzenesulfonohydrazide). Highlights: (i) simple synthesis and easy/clean work-up; (ii) hazardous condition control ( $\mathrm{POCl}_{3}$-dimethylformamide (DMF)); (iii) short reaction times and comparable yields. It also features a process with low environmental impact. Derivative $8 \mathbf{c}$ was found as the best active compound in inhibiting Colletotrichum gloeosporioides BA3 in the series compounds synthesized. For the first time, we showed that PCD derivatives cause a delay in the fungal growth for at least 2.77 days, being an interesting characteristic for the synthesis of a new agrochemical product. We believe these compounds will become promising candidates for pesticides.

\section{Experimental}

Chemical supplies for synthesis were purchased (Merck, Darmstadt, Germany or Aldrich Chemical Company, St. Louis, MO, USA). Melting points (uncorrected) were measured with a Thermo Scientific melting point apparatus, model IA 9100/capillary. To ${ }^{1} \mathrm{H}$ and ${ }^{13} \mathrm{C}$ (distortionless enhancement by polarizable transfer (DEPT)-135) NMR spectra, a Bruker Advance spectrophotometer was used, operating at 400 and $100 \mathrm{MHz}$, respectively, using tetramethylsilane (TMS) as internal standard (d, $0.0 \mathrm{ppm})$, dimethyl sulfoxide (DMSO- $d_{6}$ ) as solvent and reporting signals in ppm. Mass spectra were recorded in a Thermo Fisher Scientific GC-MS spectrometer model DSQII using a direct insertion probe and the electron impact ionization (ESI) technique $(70 \mathrm{eV})$. All reactions were monitored by TLC.

Synthesis of 5-chloro-3-methyl-1-phenyl-1 $H$-pyrazole4-carbaldehyde (2)

Phosphoryl chloride $(0.35 \mathrm{~mol}, 32 \mathrm{~mL})$ was added dropwise to ice-cold DMF $(0.16 \mathrm{~mol}, 12 \mathrm{~mL})$. To this mixture, 3-methyl-1-phenyl-5-pyrazolone (0.05 mol) was added and then refluxed during $1 \mathrm{~h}$. After cooling, the reaction mixture was poured into ice-cold water $(300 \mathrm{~mL})$. The solid which precipitated was collected by filtration, washed with water, dried and recrystallized from ethanol to give pale-yellow crystals (m.p. $144^{\circ} \mathrm{C}, 70 \%$ yield)..$^{37} \mathrm{H}$ and ${ }^{13} \mathrm{C}$ NMR spectrum are in Supplementary Information section (Figures $\mathrm{S} 1$ and $\mathrm{S} 2$ ).

Synthesis of 5-chloro-3-methyl-1-phenyl-1H-pyrazole4-carboxylic acid (3)

5-Chloro-3-methyl-1-phenyl-1H-pyrazole4-carbaldehyde $(2,5 \mathrm{mmol})$ and potassium permanganate (18 $\mathrm{mmol})$ were added to water/acetone mixture (3:2 ratio, $50 \mathrm{~mL}$ ) and heated at $80^{\circ} \mathrm{C}$, for $4 \mathrm{~h}$. The reaction mixture was filtered, acidified to $\mathrm{pH}=2$ using $\mathrm{HCl}$, to give $\mathbf{3}$ as a white solid that was filtered off and dried (95\% yield, m.p. $\left.230-231{ }^{\circ} \mathrm{C}\right) .{ }^{26}{ }^{1} \mathrm{H}$ and ${ }^{13} \mathrm{C}$ NMR spectrum are in Supplementary Information (Figures S3 and S4).

Synthesis of 5-chloro-3-methyl-1-phenyl-1 $\mathrm{H}$-pyrazole4-carbonyl chloride (5)

To 5-chloro-3-methyl-1-phenyl-1 $H$-pyrazole4-carboxylic acid $(3,2.50 \mathrm{mmol})$, thionyl chloride $(10 \mathrm{mmol})$ was added and refluxed for $2 \mathrm{~h}$. After the reaction was completed, the excess of thionyl chloride were evaporated to give $\mathbf{5}$ as a yellow liquid that was used directly without further purification. ${ }^{36}$

\section{Synthesis of pyrazole-carboxamide derivatives (8a-8d)}

To a solution of 5-chloro-3-methyl-1-phenyl$1 \mathrm{H}$-pyrazole-4-carbonyl chloride $(\mathbf{5}, 2.50 \mathrm{mmol})$ and $\mathrm{Et}_{3} \mathrm{~N}(2.5 \mathrm{mmol})$ in THF $(5 \mathrm{~mL})$, a substituted amine 
$(2.50 \mathrm{mmol})$ was added dropwise under ice-water bath $\left(0-5{ }^{\circ} \mathrm{C}\right)$. Then the mixture was vigorously stirred at ambient temperature for $10 \mathrm{~h}$. When the reaction was completed, the solvent was removed using a rotary evaporator to give a residue, which was then separated by silica gel column chromatography using petroleum ether and ethyl acetate $(\mathrm{v} / \mathrm{v}=30: 1)$ as eluent to afford the target compounds 8a-8d, with yields ranging from 72 to $87 \%$. The four pyrazole-carboxamide were prepared following this procedure.

5-Chloro-3-methyl- $N$-(naphthalen-2-yl)-1-phenyl$1 \mathrm{H}$-pyrazole-4-carboxamide (8a)

Yellow solid, m.p. $188-190{ }^{\circ} \mathrm{C}$, yield $72 \%$; ${ }^{1} \mathrm{H}$ NMR $\left(400 \mathrm{MHz}\right.$, DMSO- $\left.d_{6}\right) \delta 2.47$ (s, 3H, $\left.\mathrm{CH}_{3}\right), 7.52-7.61(\mathrm{~m}, 8 \mathrm{H}$, aryl), 7.76 (d, 2H, aryl), 7.83 (d, 2H, aryl), 7.96 (d, 2H, aryl), 8.09 (d, 2H, aryl), 10.13 (s, 1H, NH); ${ }^{13} \mathrm{C}$ NMR $(100 \mathrm{MHz}$, DMSO- $\left.d_{6}\right) \delta 13.6,122.6,123.0,125.5,125.8,126.2,126.4$, 126.9, 128.4, 129.2, 129.6, 133.5, 134.0, 137.5, 149.3, 161.3; MS (ESI, positive scan $70 \mathrm{eV}$ ) $\mathrm{m} / z, 361\left[\mathrm{M}^{+}\right]$.

5-Chloro- $N$-(4-methoxybenzyl)-3-methyl-1-phenyl$1 \mathrm{H}$-pyrazole-4-carboxamide (8b)

White solid, m.p. $148-152{ }^{\circ} \mathrm{C}$, yield $84 \%$; ${ }^{1} \mathrm{H}$ NMR $\left(400 \mathrm{MHz}, \mathrm{DMSO}-d_{6}\right) \delta 2.34$ (s, 3H, $\mathrm{CH}_{3}$ ), 3.73 (s, 3H, $\left.\mathrm{OCH}_{3}\right), 4.38\left(\mathrm{~s}, 2 \mathrm{H}, \mathrm{CH}_{2}\right), 6.89(\mathrm{~d}, 2 \mathrm{H}, J 8.41 \mathrm{~Hz}$, aryl), 7.26 (d, 2H, $J 8.41 \mathrm{~Hz}$, aryl), 7.51-7.57 (m, 5H, phenyl), 8.42 (s, $1 \mathrm{H}, \mathrm{NH}) ;{ }^{13} \mathrm{C}$ NMR (100 MHz, DMSO- $\left.d_{6}\right) \delta 13.4$, 41.8, 55.0, 113.7, 115.1, 125.3, 125.9, 128.5, 128.8, 129.3, 131.3, 137.3, 148.7, 158.2, 161.3; MS (ESI, positive scan $70 \mathrm{eV}) \mathrm{m} / \mathrm{z}, 355\left[\mathbf{M}^{+}\right]$.

$N$-(5-Chloro-3-methyl-1-phenyl-1H-pyrazole-4-carbonyl)4-methylbenzenesulfonohydrazide (8c)

Yellow solid, m.p. $155-157{ }^{\circ} \mathrm{C}$, yield 79\%; ${ }^{1} \mathrm{H}$ NMR $\left(400 \mathrm{MHz}, \mathrm{DMSO}-d_{6}\right) \delta 2.24\left(\mathrm{~s}, 3 \mathrm{H}, \mathrm{CH}_{3}\right), 2.36(\mathrm{~s}, 3 \mathrm{H}$, $\mathrm{CH}_{3}$ ), 7.35-7.37 (d, $2 \mathrm{H}, J 8.06 \mathrm{~Hz}$, aryl), 7.49-7.56 (m, 5H, phenyl), 7.76-7.78 (d, 2H, J 8.06 Hz, aryl), 10.26 (s, 1H, $\mathrm{NH}) ;{ }^{13} \mathrm{C}$ NMR $\left(100 \mathrm{MHz}\right.$, DMSO- $\left.d_{6}\right) \delta 13.6,21.6,113.2$, 125.8, 127.7, 128.4, 129.5, 129.8, 136.4, 137.6, 143.9, 149.2, 160.9; MS (ESI, positive scan $70 \mathrm{eV}$ ) $\mathrm{m} / z, 404\left[\mathrm{M}^{+}\right]$.

5-Chloro- $N$-cyclohexyl-3-methyl-1-phenyl-1 $H$-pyrazole4-carboxamide (8d)

White solid, m.p. $140-142{ }^{\circ} \mathrm{C}$, yield $87 \%$; ${ }^{1} \mathrm{H}$ NMR (400 MHz, DMSO- $\left.d_{6}\right) \delta 1.26-1.32\left(\mathrm{~m}, 5 \mathrm{H}, \mathrm{CH}_{2}\right), 1.70-$ $1.82\left(\mathrm{~m}, 5 \mathrm{H}, \mathrm{CH}_{2}\right), 2.30\left(\mathrm{~s}, 3 \mathrm{H}, \mathrm{CH}_{3}\right), 3.72(\mathrm{~s}, 1 \mathrm{H}, \mathrm{CH})$, 7.49-7.62 (m, 5H, phenyl), 7.87 (s, $1 \mathrm{H}, \mathrm{NH}) ;{ }^{13} \mathrm{C} \mathrm{NMR}$ $\left(100 \mathrm{MHz}, \mathrm{DMSO}-d_{6}\right) \delta 13.2,24.6,25.3,32.3,47.9,115.9$, 125.3, 125.7, 128.8, 129.4, 137.4, 148.4, 160.4; MS (ESI, positive scan $70 \mathrm{eV}$ ) $\mathrm{m} / \mathrm{z}, 317\left[\mathrm{M}^{+}\right]$.
Biological tests

\section{Strains}

Colletotrichum gloeosporioides strains, identified by sequencing as Colletotrichum gloeosporioides BA3 and with a high degree of pathogenesis, provided by Agricultural Bioprospecting Research Group of the Microbiological Research Laboratory, the Faculty of Agricultural Sciences of the Universidad de Sucre-Colombia, were used as fungal strains for the antifungal activity evaluation of the pyrazole-derivatives.

\section{Antifungal activity assay of derivatives $\mathbf{8 a - 8 d}$}

Antifungal activity was determined as mycelial growth inhibition following the method reported. ${ }^{39}$ Petri dishes were inoculated in potato dextrose agar (PDA, BD Difco, USA) and the fungal growth was analyzed in presence of derivatives diluted in DMSO to reach solutions with a final concentration of 1,5 and $10 \mathrm{mM}$ and incubated at $27^{\circ} \mathrm{C}$. During ten days, the diameter of the colonies were measured daily using a Caliper and the data obtained were fitted with the Gompertz equation modified ${ }^{44}$ to estimate the main growth parameters: $\lambda$ (lag time), $\mu_{\max }$ (the maximum exponential growth rate), and $\mathrm{A}_{\max }$ (maximum growth value) as follow in equation 1:

$\ln (\mathrm{Dt} / \mathrm{Do})=\mathrm{A}_{\max } \exp \left\{-\exp \left[\left(\mu_{\max } \mathrm{e} / \mathrm{A}_{\max }\right)(\lambda-\mathrm{t})+1\right]\right\}$

where $\mathrm{Dt}(\mathrm{cm})$ is the average colony diameter at each time of the experiment, Do $(\mathrm{cm})$ is the average colony diameter at the beginning of the experiment, $A_{\max }$ is the maximum colony diameter achieved during the stationary phase, $\mu_{\max }$ is the maximum growth rate (1/day) and $\lambda$ is the lag phase (day).

\section{Statistical analysis}

Data on inhibitory effect of the pyrazole-derivatives DMSO solutions were subjected to analysis of variance (ANOVA) and Duncan test for comparison of means with the software Statistica. ${ }^{45}$ The results are presented as mean values \pm standard deviation (SD).

\section{Supplementary Information}

Supplementary information (MS, ${ }^{1} \mathrm{H}$ and ${ }^{13} \mathrm{C}$ NMR spectra for $\mathbf{2}, \mathbf{3}$ and $\mathbf{8}$ ) is available free of charge at http://jbcs.sbq.org.br as PDF file.

\section{Acknowledgments}

This work was supported financially by support program for Young Researchers and Innovators for Peace 775/2017, 
Colciencias (Convenio Especial de Cooperación No. FP44842-453-2017, subscribed between the Universidad del Atlántico y la Fiduciaria Previsora S.A). Edwin González-López is sponsored by Colciencias (775/2017). The authors thank the Universidad del Atlántico and Universidad del Valle.

\section{Author Contributions}

Edwin González-López and Jhair León-Jaramillo carried out the experimental part, formal analysis; Carlos D. Grande-Tovar and Yeimmy Peralta-Ruiz implemented and carried out biological tests, statistical analysis and validation; Jairo Quiroga contributed with technical support and data curation; Jorge Trilleras was responsible for the conceptualization, project administration and writing original draft; Carlos D. Grande-Tovar for writing review and editing. All authors read and approved the final version of the manuscript.

\section{References}

1. Thuy, G. L.; Abhijit, K.; Atanu, G.; Nghi, H.; Nguyen, S. P.; Yaqing, J.; Banfeng, R.; Lian, X.; Fei, H.; Keiser, J.; Hofmann, A.; Chang, B. C. H.; García-Bustos, J.; Wells, T. N. C.; Palmer, M. J.; Jabbar, A.; Gasser, R. B.; Baell, J. B.; J. Med. Chem. 2019, 62, 1036.

2. Zhang, J.; Peng, J. F.; Wang, T.; Kang, Y.; Jing, S.; Zhang, Z.-T.; Mol. Diversity 2017, 21, 317.

3. Khan, M. F.; Alam, M. M.; Verma, G.; Akhtar, W.; Akhter, M.; Shaquiquzzaman, M.; Eur. J. Med. Chem. 2016, 120, 170.

4. Havrylyuk, D.; Roman, O.; Lesyk, R.; Eur. J. Med. Chem. 2016, $113,145$.

5. Küçükgüzel, Ş. G.; Şenkardeş, S.; Eur. J. Med. Chem. 2015, 97, 786.

6. Xu, C.; Li, M.; Zhou, Z.; Li, J.; Chen, D.; Duan, Y.; Zhou, M.; Toxins 2019, 11, 272.

7. Kumar, A.; Fernandes, J.; Kumap, P.; Orient. J. Chem. 2014, 30, 1993.

8. Xiang, Y.; Zhang, Y.; Wang, C.; Liu, S.; Liao, X.; Pestic. Biochem. Physiol. 2017, 147, 32.

9. Pinto, L. S. R. C.; Azevedo, J. L.; Pereira, J. O.; Vieira, M. L. C.; Labate, C. A.; New Phytol. 2000, 147, 609.

10. Saremi, H.; Okhovvat, S. M.; Ashrafi, S. J.; Afr. J. Biotechnol. 2011, 10, 18391.

11. Riera, N.; Ramirez-Villacis, D.; Barriga-Medina, N.; AlvarezSantana, J.; Herrera, K.; Ruales, C.; Leon-Reyes, A.; Plant Dis. 2019, 103, 763.

12. Pardo-De La Hoz, C. J.; Calderón, C.; Rincón, A. M.; Cárdenas, M.; Danies, G.; López-Kleine, L.; Jiménez, P.; Plant Pathol. 2016, 65, 227.
13. Garrigues, S.; Gandía, M.; Marcos, J. F.; Appl. Microbiol. Biotechnol. 2016, 100, 2243.

14. Guan, A.; Liu, C.; Yang, X.; Dekeyser, M.; Chem. Rev. 2014, $114,7079$.

15. Vilaplana, R.; Chicaiza, G.; Vaca, C.; Valencia-Chamorro, S.; Crop Prot. 2020, 128, 105007.

16. Quintero Mercado, A.; Dangon-Bernier, F.; Páez-Redondo, A.; Rev. Acad. Colomb. Cienc. Exactas, Fis. Nat. 2019, 43, 65.

17. Zhang, A.; Zhou, J.; Tao, K.; Hou, T.; Jin, H.; Bioorg. Med. Chem. Lett. 2018, 28, 3042.

18. Keri, R. S.; Chand, K.; Ramakrishnappa, T.; Nagaraja, B. M.; Arch. Pharm. 2015, 348, 299.

19. Jeschke, P.; Pest Manage. Sci. 2010, 66, 10.

20. Peng, H.; Zhang, P.; Bilal, M.; Wang, W.; Hu, H.; Zhang, X.; Microb. Cell Fact. 2018, 17, 117.

21. Juliatti, F.; Polloni, L.; de Morais, T.; Zacarias, S.; Silva, E.; Juliatti, B.; Biosci. J. 2017, 33, 933.

22. Szmuszkovicz, J.; Chidester, C. G.; Laurian, L. G.; Scahill, T. A.; J. Org. Chem. 1986, 51, 5002.

23. Huang, D.; Liu, A.; Liu, W.; Liu, X.; Ren, Y.; Zheng, X.; Pei, H.; Xiang, J.; Huang, M.; Wang, X.; Heterocycl. Commun. 2017, $23,455$.

24. Hranjec, M.; Sovic, I.; Ratkaj, I.; Pavlovic, G.; Ilic, N.; Valjalo, L.; Pavelic, K.; Pavelic, S. K.; Karminski-Zamola, G.; Eur. J. Med. Chem. 2013, 59, 111.

25. Jeanmart, S.; Edmunds, A. J. F.; Lamberth, C.; Pouliot, M.; Bioorg. Med. Chem. 2016, 24, 317.

26. Mu, J.-X.; Shi, Y.-X.; Yang, M.-Y.; Sun, Z.-H.; Liu, X.-H.; Li, B.-J.; Sun, N.-B.; Molecules 2016, 21, 68.

27. Wu, J.; Shi, Q.; Chen, Z.; He, M.; Jin, L.; Hu, D.; Molecules 2012, 17, 5139.

28. Zhao, D.; Sun, B.; Ren, J.; Li, F.; Song, S.; Lv, X.; Hao, C.; Cheng, M.; Bioorg. Med. Chem. 2015, 23, 1356.

29. Sun, B.; Liu, K.; Han, J.; Zhao, L.-Y.; Su, X.; Lin, B.; Zhao, D.-M.; Cheng, M.-S.; Bioorg. Med. Chem. 2015, 23, 6763.

30. Abdel-Wahab, B. F.; Khidre, R. E.; Farahat, A. A.; ARKIVOC 2011, $i, 196$.

31. Abu-Zaied, M. A.; El-Telbani, E. M.; Elgemeie, G. H.; Nawwar, G. A. M.; Eur. J. Med. Chem. 2011, 46, 229.

32. Kasımogulları, R.; Arslan, B. S.; J. Heterocycl. Chem. 2010, 47, 1040 .

33. Kasımogulları, R.; Duran, H.; Yaglıglu, A. S.; Mert, S.; Demirtas, I.; Monatsh. Chem. 2015, 146, 1743.

34. Minnelli, C.; Laudadio, E.; Galeazzi, R.; Rusciano, D.; Armeni, T.; Stipa, P.; Cantarini, M.; Mobbili, G.; Antioxidants 2019, 8, 258.

35. Ali, Z. K.; Baker, D. E.; Hosp. Pharm. 2017, 52, 732.

36. Xiao, J.-J.; Liao, M.; Chu, M.-J.; Ren, Z.-L.; Zhang, X.; Lv, X.-W.; Cao, H.-Q.; Molecules 2015, 20, 807.

37. Trilleras, J.; Quiroga, J.; Cobo, J.; Low, J. N.; Glidewell, C.; Acta Crystallogr., Sect. E: Crystallogr. Commun. 2005, 61, 1055 . 
38. Liu, X.; Qiao, L.; Zhai, Z.; Cai, P.; Charles, L.; Tan, C.; Weng, J.; Wu, H.; Pest Manage. Sci. 2019, 75, 2892.

39. Grande-Tovar, C. D.; Chaves-López, C.; Viuda-Martos, M.; Serio, A.; Delgado-Ospina, J.; Pérez-Alvarez, J. A.; Ospina, N.; la Tora, S.; Palmieri, S.; Paparella, A.; Ind. Crop. Prod. 2016, 87, 315 .

40. Apaydın, S.; Török, M.; Bioorg. Med. Chem. Lett. 2019, 29, 2042.

41. Cai, N.; Liu, C.; Feng, Z.; Li, X.; Qi, Z.; Ji, M.; Qin, P.; Ahmed, W.; Cui, Z.; Molecules 2018, 23, 720.
42. Zoumpoulakis, P.; Camoutsis, C.; Pairas, G.; Soković, M.; Glamočlija, J.; Potamitis, C.; Pitsas, A.; Bioorg. Med. Chem. 2012, 20, 1569.

43. Oliveira, P. D. L.; de Oliveira, K. Á. R.; Vieira, W. A. S.; Câmara, M. P. S.; de Souza, L. L.; Int. J. Food Microbiol. 2018, 266, 87.

44. Zwietering, M. H.; Jongenburger, I.; Rombouts, F. M.; van't Riet, K.; Appl. Environ. Microbiol. 1990, 56, 1875.

45. Statistica, version 13.3; StatSoft Inc., USA, 2017.

Submitted: January 31, 2020

Published online: May 19, 2020 